\title{
Evolução da Qualidade das Práticas de Governança Corporativa: um Estudo das Empresas Brasileiras de Capital Aberto Não Listadas em Bolsa
}

\section{Evolution of the Quality of the Practical of Corporate Governance: a Study of Nonlisted the Brazilian Companies in Stock Exchange}

Moisés Araújo Almeida * Doutorando em Administração pelo PROPAD/UFPE. Professor Assistente da UFS, Itabaiana/SE, Brasil.

Joséte Florencio dos Santos Doutora em Administração pelo COPPEAD/UFRJ. Professora Adjunta do PROPAD/UFPE, Recife/PE, Brasil.

Lúcio Flávio Vieira de Medeiros Ferreira Graduado em Administração da UFPE, Recife/PE, Brasil.

Fernando José Vieira Torres Mestre em Administração pela UFPE. Professor Assistente da UFPB, João Pessoa/PB, Brasil.

* Endereço: Moisés de Araújo Almeida

Avenida Vereador Olímpio Grande, s/n, Bairro Centro, Departamento de Ciências Contábeis/UFS, Itabaiana/SE, 49500-000. E-mail: moisesalmeida@ufs.br

Copyright (C) 2010 RAC. Todos os direitos, inclusive de tradução, são reservados. É permitido citar parte de artigos sem autorização prévia desde que seja identificada a fonte. 


\title{
RESUMO
}

Este artigo tem por objetivo analisar a evolução da qualidade das práticas de governança corporativa das empresas brasileiras de capital aberto não listadas em bolsa, no período de 2003 a 2007. Os dados foram coletados através do Sistema DIVEXT da CVM. Como proxy para determinar a qualidade das práticas de governança, foi utilizado o Índice de Governança Corporativa das Empresas Brasileiras de Capital Aberto Não Listadas em Bolsa, calculado a partir de um conjunto de 14 perguntas binárias e objetivas. Os resultados da pesquisa apontam que metade das empresas investigadas apresentou bom nível de governança. Em relação à dimensão Transparência, verificou-se uma melhora na elaboração de relatórios financeiros, obedecendo aos prazos legais e que cerca da metade das companhias contrataram alguma das auditorias globais. Quanto à Composição e Funcionamento do Conselho não foram constatados sinais de melhoria, justificada pela diminuição do atendimento às exigências no que se refere à quantidade de membros, independência e prazo de mandato. Já os resultados da estrutura de Controle e Conduta mostram que a grande maioria das empresas não possuía acordos entre acionistas, significando evolução positiva no sentido de boas práticas de governança.

Palavras-chave: governança corporativa; empresas de capital aberto; índice de governança.

\begin{abstract}
This article analyzes the evolution of the quality of corporate governance practices by Brazilian companies that are non listed on the stock exchange from 2003 through 2007. The data were collected through System DIVEXT of the CVM. As a proxy for determining the quality of corporate governance practices, the Corporate Governance Index of the Brazilian Companies Unlisted on Stock Exchange was used, calculated from a set of 14 binary and objective questions. The results of the research show that half of the companies under study had a good level of governance. Concerning the Transparency dimension, the findings showed that there had been an improvement in the drafting of financial reports and that legal deadlines were being met. Furthermore, approximately half of the companies had contracted some form of global auditing. In the Composition and Functioning of Advice there were no signs of improvement, due to less concern over demands concerning the number of members, independence and length of mandate. The results of the Structure of Control and Behavior show that the vast majority of the companies had no agreements between shareholders. This is a positive improvement in good governance practices.
\end{abstract}

Key words: corporate governance; open-capital companies; corporate governance index. 


\section{INTRODUÇÃO}

No trabalho intitulado de The Modern Corporation and Private Property, Berle e Means (1932) enfocaram os aspectos relacionais da propriedade e do controle. As bases da teoria apresentadas por eles caracterizam a relação de agência entre um mandatário (principal) e um ou mais agentes, investidos de poderes para representar os interesses e tomar decisões em nome do principal. A partir do momento em que ocorre a separação entre a propriedade e o controle das organizações, surgem os chamados problemas de agência. Jensen e Meckling (1976) apresentaram artigo seminal com escopo teórico sobre a teoria da agência. Os autores defendem que os problemas de agência surgem com essa separação entre propriedade e controle, devido às diferenças de motivação e objetivos, assimetria de informação e preferências de risco que existem entre os proprietários e os gestores.

Para minimizar os prejuízos causados pelos problemas de agência faz-se necessária a adoção de alguns mecanismos de governança. Shleifer e Vishny (1997) ressaltam que, em países menos desenvolvidos, praticamente não existem mecanismos de governança. A governança corporativa coloca em pauta questões relevantes, como o papel do conselho de administração, dos executivos e da administração das empresas, com a finalidade de estabelecer normas de conduta e definir responsabilidades. Através dos mecanismos de monitoramento e controle, a governança objetiva a proteção dos acionistas e credores, de forma que eles não possam ser expropriados pelos agentes da organização.

A governança tem despertado interesse do mercado em função das mudanças ocorridas no cenário mundial, dos escândalos corporativos ocorridos nos últimos anos, principalmente no mercado norteamericano, que é reconhecido como o principal fornecedor de capital do mundo. Além disso, os processos de privatizações, fusões e aquisições, e o crescimento dos fundos de pensão também contribuíram para a preocupação com os estudos da governança das corporações. Todo esse processo tem impactado e promovido mudanças nas legislações dos diversos países, os quais têm buscado estabelecer regras mais claras e transparentes como forma de garantir maior proteção aos investidores e criar ambiente favorável ao alinhamento de interesses.

Muitos países desenvolveram seus códigos segundo os princípios de melhores práticas de governança corporativas discutidas e orientadas pela Organisation for Economic Co-operation and Development [OECD]. Com eles espera-se que seja criado ambiente favorável ao alinhamento de interesses entre acionistas e gestores, por exemplo e, com isto, abrandar os problemas de agência. A boa governança resultaria da adoção de mecanismos que conduziriam os gestores a proteger os interesses dos acionistas. Para o Instituto Brasileiro de Governança Corporativa [IBGC] (2004) as boas práticas de governança corporativa têm a finalidade de aumentar o valor da sociedade, facilitar seu acesso ao capital e contribuir para a sua perenidade.

Os grandes escândalos das empresas norte-americanas ocasionaram modificações na legislação do mercado financeiro. Criada em 2002 nos EUA, a Lei de Sarbanes-Oxley [SOX] tem como base princípios de governança corporativa e foca principalmente a responsabilidade penal da diretoria. Repleta de reformas para governança corporativa, divulgação e contabilidade, a nova Lei busca reparar a perda da confiança pública nos líderes empresariais norte-americanos e enfatizar, mais uma vez, a importância dos padrões éticos na preparação de suas informações financeiras (Oliveira, 2006). Em resumo, a SOX busca proteção aos acionistas e à sociedade contra fraudes.

No caso brasileiro, os níveis diferenciados de governança corporativa criados pela Bolsa de Valores de São Paulo [Bovespa] (2008), no final do ano 2000, possuem critérios de adesão que buscam diminuir a assimetria informacional entre os investidores e as empresas participantes destes grupos, através de maior transparência das informações divulgadas, e reduzir o custo de captação de recursos no mercado. A implantação de três segmentos especiais para listagem de ações, denominados Nível 1, Nível 2 e Novo Mercado, teve por objetivo proporcionar um ambiente de negociação que estimule o interesse dos investidores e a valorização das companhias. O que distingue cada um deles é o grau de comprometimento com as regras específicas de governança. Entretanto as empresas de capital aberto, 
não listadas em bolsa, não estão submetidas a estas orientações; mas visa-se potencialmente a que as possíveis empresas adiram a este mercado.

Segundo a OECD (2005), enquanto o debate sobre governança corporativa tem focado principalmente as companhias listadas nos países com mercados de capitais desenvolvidos, os desafios da governança corporativa em empresas não listadas merecem atenção especial, sobretudo nos países onde os mercados de capitais são menos desenvolvidos.

Dada a relevância do tema, a adoção de boas práticas de governança corporativa tem sido preocupação não apenas dos acionistas, mas também das instituições públicas que regulam e normatizam as relações no mercado de capitais. Algumas questões, conforme apresentado pela OECD (2005), aumentam o debate sobre governança corporativa deste grupo de empresas, formulando perguntas como as seguintes: Quais são as características de governança corporativa das companhias não listadas? Que é que impulsiona a melhoria das suas práticas de governança? Qual o papel das políticas públicas no apoio das boas práticas de governança corporativa para elas? Enquanto há similaridades substanciais nos problemas imaginados para ambos os tipos de companhias, listadas e não listadas, a estrutura organizacional típica de companhias não listadas parecem demandar, em algumas instâncias, abordagem diferente daquela apresentada pelas empresas listadas.

As empresas não listadas representam parcela importante das empresas de capital aberto e possuem relevante participação na economia brasileira; praticamente não há estudos que as explorem. Ademais, é um grupo de empresas que merece ser estudado, pois são, em potencial, as empresas que podem fortalecer e incrementar o mercado de capitais brasileiro.

Por outro lado, os estudos, de modo geral, têm apresentado resultados sobre as empresas de capital aberto listadas em bolsa e, praticamente, não abordam a parcela de empresas pretendidas neste estudo. Portanto, este trabalho visa cobrir esta lacuna, procurando observar as variáveis que têm alguma influência nas práticas de governança corporativa das empresas de capital aberto não listadas em bolsa.

Tendo como pressuposto o referencial teórico sobre governança corporativa, a presente pesquisa busca responder à seguinte pergunta: Como está a qualidade das práticas de governança corporativa das empresas brasileiras de capital aberto não listadas em bolsa de valores?

O presente estudo tem por objetivo analisar a evolução da qualidade das práticas de governança corporativa das empresas brasileiras de capital aberto não listadas em bolsa de valores, no período de 2003 a 2007.

Nesse sentido, este estudo contribui para a literatura sobre governança corporativa, visto que há um número reduzido de pesquisas sobre empresas brasileiras de capital aberto não listadas em bolsa, que busquem caracterizar a qualidade das práticas de governança corporativa dessas organizações. A pesquisa proposta será também uma contribuição para a discussão do tema no Brasil; haja vista a importância que a governança vem assumindo no ambiente acadêmico e empresarial. Além da introdução, o artigo apresenta-se dividido nas seguintes seções: referencial teórico, procedimentos metodológicos, análise dos resultados, considerações finais e referências.

\section{REFERENCIAL TEÓRICO}

A definição utilizada para empresas de capital aberto é dada segundo a Lei $n^{\circ} 6.404$ (1976) e Lei ${ }^{\circ}$ 10.303 (2001) e suas posteriores alterações, que referenciam como empresa aberta aquelas que têm o capital dividido em ações, limitando a responsabilidade de cada sócio ao preço de emissão das ações subscritas ou adquiridas. O termo "não listada" refere-se às empresas abertas que não possuem ações negociadas em bolsa. 
O tema governança corporativa tem tido mais atenção recentemente, com a intensificação dos debates há cerca de três décadas. O termo tornou-se mais presente na literatura de administração de empresas no início dos anos oitenta, mas é atualmente motivo de discussão em diversas áreas. A governança corporativa tem sido discutida nas áreas de direito, economia, contabilidade e finanças, e envolve amplo debate tanto no meio acadêmico quanto no ambiente empresarial. O conceito de governança corporativa apresentado por Shleifer e Vishny (1997) enfatiza os aspectos financeiros. Eles definem governança corporativa como o conjunto de mecanismos pelos quais os fornecedores de recursos garantem que obterão para si o retorno do seu investimento. Por outro lado, a OECD (2008) define governança corporativa como um conjunto de relações entre a gerência corporativa e o conselho diretivo e demais grupos que possuam algum vínculo direto com a empresa. A estrutura da governança especifica a atribuição dos direitos e responsabilidades dos diferentes participantes da empresa, como dirigentes, acionistas e outras partes interessadas (stakeholders), e detalha as regras e procedimentos para tomada de decisões no que se refere aos assuntos corporativos. Por isso, fornece a estrutura pela qual os objetivos da companhia são definidos, tanto quanto se definem os meios para atingir estes objetivos e monitorar seu desempenho.

Para Shleifer e Vishny (1997), a perspectiva de governança corporativa é a definição clara da perspectiva de agência. Portanto, por governança corporativa entende-se o conjunto de mecanismos com a finalidade de monitorar a gestão e o desempenho das organizações, de forma que os interesses dos administradores estejam de acordo com os interesses dos proprietários.

Silva e Leal (2007) ressaltam que o conceito de governança corporativa não se restringe apenas às empresas que possuem capital aberto e são listadas em bolsa, mas se aplica a todas as empresas que buscam uma relação de transparência e confiança com as partes com que mantêm algum relacionamento. Assim, torna-se relevante o estudo das práticas de governança das empresas de capital aberto e não listadas, propósito da presente pesquisa.

A governança corporativa fornece ao mercado de capitais informações relevantes para a tomada de decisões. De acordo com Ariff, Ibrahim e Othman (2007), além das informações sobre a saúde financeira e o desempenho das companhias, os investidores também precisam saber como essas companhias estão sendo administradas. Segundo eles, a qualidade das práticas de governança corporativa é vista como fonte de informação que fornece critério adicional à tomada de decisão.

Para mensurar a qualidade das práticas de governança corporativa, Black (2001) utilizou classificações de governança de 21 empresas da Rússia, desenvolvidos por um banco de investimento. Os resultados deste estudo evidenciam que, ao melhorar suas práticas de governança, as empresas podem melhorar os preços de suas ações e assim reduzir o custo de capital. $\mathrm{O}$ autor enfatiza que estes resultados podem ser aplicados aos demais países que também estão em fase de desenvolvimento, mas com algumas limitações, pois se referem a uma pequena amostra.

Klapper e Love (2002) focaram suas atenções no papel da proteção legal dos investidores de diferentes países. Elas observaram que empresas de um mesmo país podem oferecer diferentes níveis de proteção dos investidores, com a adoção de mecanismos não especificados por lei, e que existe variação nos padrões de governança num mesmo país. Ainda constataram que existe relação entre os mecanismos de governança da empresa e o nível de proteção legal dos investidores. Como medida de mensuração da qualidade das práticas de governança corporativa, as autoras utilizaram os escores elaborados pelo Credit Lyonnais Securities Asia [CLSA], e verificaram que o índice de governança da empresa é positivamente relacionado com medidas de proteção do investidor, ou seja, a governança em média é mais alta nos países com mais forte proteção legal.

O índice de governança elaborado por Gompers, Ishii e Metrick (2003), com uma amostra de 1.500 empresas norte-americanas, adiciona um ponto para cada requisito que restringe os direitos dos acionistas e, conseqüentemente, aumenta o poder gerencial, de tal forma que o índice final é a soma de pontos para a existência (ou ausência) de cada requisito de governança analisado.

Outros pesquisadores construíram o índice que mensura a qualidade das práticas de governança corporativa, tendo como base as recomendações e sugestões apresentadas pelos códigos de melhores 
práticas de governança corporativa. Baseado nas regras de governança da Coréia, Black, Jang e Kim (2005) construíram o índice de governança corporativa, com dados de 515 companhias listadas na bolsa coreana no ano de 2001, por meio de cinco sub-índices: direitos dos acionistas, estrutura do conselho, normas do conselho, transparência e igualdade de propriedade. Para sua elaboração, foram utilizadas questões binárias, sendo igual a 1 (um) se empresa apresenta determinada variável de governança; caso contrário, igual a 0 (zero), de tal forma que o índice é o resultado da soma dos escores, que podem variar de 0 (zero) a 100. Estes autores observaram que melhores práticas de governança estão associadas com maior valorização das ações da companhia, bem como à composição do conselho de administração que, com $50 \%$ de diretores externos, provoca aumento de sua avaliação pelo mercado, mensurado através do Q de Tobin e do preço das ações.

Drobetz, Gugler e Hirschvogl (2004) utilizaram um rating de governança corporativa amplo, que foi construído baseado nas respostas de um survey enviado às empresas alemãs de capital aberto, tendo uma amostra composta por 91 empresas. Para qualificar a inclusão no rating de governança corporativa, cada prática tinha de referir-se a um elemento de governança que ainda não fosse legalmente exigido e era necessário que fosse considerada como uma das melhores práticas de governança corporativa no mercado internacional. No total, o rating envolve 30 proxies de governança corporativa e está dividido em cinco categorias: compromisso com governança corporativa, direitos dos acionistas, transparência, importância do conselho na administração e na supervisão, e, auditoria. Os princípios de construção do rating de governança são simples: primeiro, o mais alto nível de aceitação de uma variável proxy indica um movimento ativo da administração da empresa em ter melhorado seu sistema de governança; segundo, 25 pontos de base foram adicionados para cada nível de aceitação da proxy respectiva na escala de resposta, variando até cinco; para cada empresa o rating agregado é a soma ponderada dos pontos de base de todas as proxies, alcançando de 0 (mínimo) a 30 (máximo).

Beiner, Drobetz, Schmid e Zimmerman (2003) utilizaram a mesma metodologia para elaborar o índice de governança corporativa, o qual foi realizado com uso de questionário detalhado, que contém as sugestões e recomendações do Código Suíço de Melhores Práticas. O questionário foi enviado a todas as empresas listadas na Bolsa de Valores da Suíça, com exceção das companhias de investimento; quando necessário, os dados foram suplementados e verificados na base de relatórios anuais e páginas da web. Os resultados deste estudo confirmam a existência de uma relação positiva entre governança corporativa e valor da empresa. Os autores verificaram que o aumento de um ponto no índice de governança corporativa causa aumento de 8\%, em média, na capitalização de mercado do valor do ativo da companhia.

Com o objetivo de medir a qualidade da governança das empresas brasileiras, Leal e Carvalhal-daSilva (2004) desenvolveram um índice de governança corporativa, que conta com 24 questões binárias, cujas respostas foram obtidas a partir de informações públicas, e serve como medida ampla da qualidade da governança corporativa das empresas. Cada resposta positiva adiciona um ponto ao índice, ao passo que uma reposta negativa tem valor zero. O índice é constituído pela soma dos pontos de cada questão, sendo o valor máximo de 24 pontos; ele contempla as recomendações constantes dos códigos de melhores práticas de governança corporativa do IBGC, da CVM e da Bovespa; é dividido em quatro categorias: transparência; composição e funcionamento do conselho; estrutura de propriedade e controle; e direitos dos acionistas. De maneira similar, e alguns com adaptações, este índice foi utilizado nas empresas brasileiras por outros pesquisadores, a exemplo de Nobili (2006), Silva e Leal (2007) e Silveira, Leal, Carvalhal-da-Silva e Barros (2007).

A pesquisa desenvolvida por Silveira (2004) buscou avaliar se os mecanismos de governança corporativa são determinados a partir de características observáveis das empresas e se exercem influência no desempenho das companhias brasileiras listadas. Dentre os fatores que fazem com que algumas empresas apresentem nível de governança maior do que outras, no Brasil, destacaram-se os determinantes relacionados à estrutura de propriedade, cujos resultados sugerem que a concentração de propriedade influencia a qualidade da governança corporativa. O autor constatou o seguinte: quanto maior o poder do acionista controlador, em termos de direito de voto e em termos de disparidade entre direito de voto e direito sobre o fluxo de caixa, pior a qualidade da governança 
corporativa. Os resultados também indicaram que o desempenho pode influenciar a qualidade da governança corporativa, sugerindo que as empresas com melhor desempenho adotam melhores práticas de governança. Quanto à variável unificação de cargos de diretor executivo e presidente do conselho, os resultados sugerem que as empresas que possuem a mesma pessoa ocupando os dois cargos auferem menores margens de lucro.

Observa-se, de maneira geral, o uso de índices, obtidos a partir das respostas de questionários que procuram mensurar a qualidade das práticas de governança corporativa no Brasil. As informações têm sido coletadas de forma objetiva, diretamente pelos pesquisadores, com uso de questões que contemplem diferentes dimensões da governança, baseado em regras legais ou em recomendações dos códigos de governança e com a obtenção de informações em bancos de dados disponíveis na internet. As vantagens de utilização de um índice, baseado em questionários para indicar a qualidade das práticas de governança corporativa são: ele usa informações transparentes, é de fácil replicação, uma vez que não requer julgamentos subjetivos, possibilita fácil interpretação, evita viés e a baixa taxa de respondentes, observados quando se utilizam questionários respondidos por representantes das empresas.

\section{PROCEDIMENTOS METOdOLÓGICOS}

\section{Amostra e Coleta de Dados}

A população da pesquisa foi formada por todas as empresas abertas brasileiras não listadas em bolsa, registradas na Comissão de Valores Mobiliários [CVM] entre o período de 2003 e 2007. Este período foi escolhido em função da disponibilidade dos dados investigados.

O universo da pesquisa é composto por 155 empresas em 2003; 174 empresas em 2004; 118 empresas em 2005; 223 empresas em 2006; e 85 empresas em 2007.

A amostra foi composta pelas empresas que disponibilizaram todas as informações necessárias para a realização da pesquisa. O número de empresas que compõe a amostra investigada é apresentado na Figura 1 a seguir.

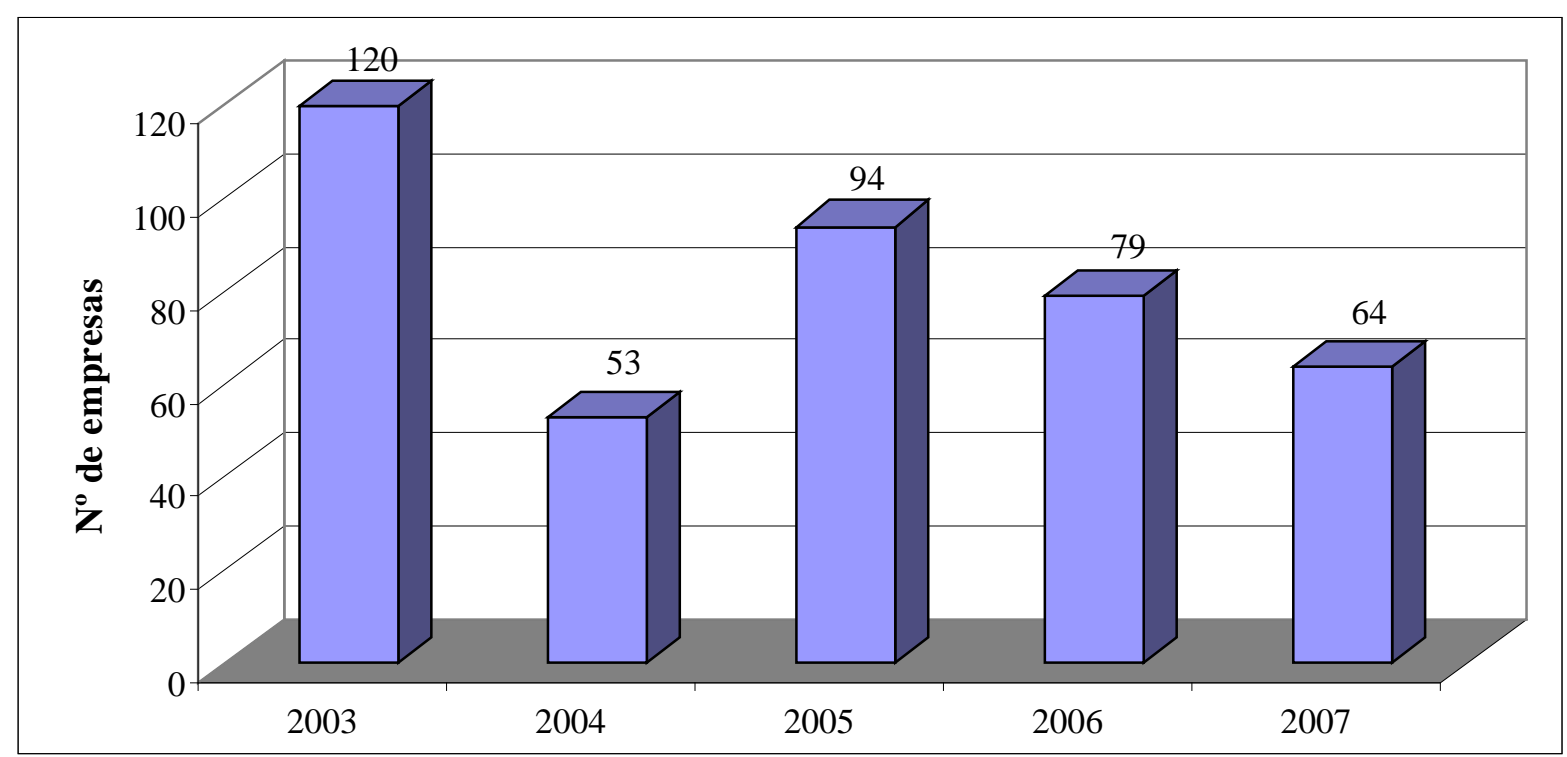

Figura 1. Amostra da Pesquisa Fonte: os autores. 
Pode-se observar grande oscilação no número de empresas da amostra (ver Figura 1). O ano de 2004 apresentou o menor número de empresas da amostra; paralelamente também foi o ano em que a CVM cancelou o registro de grande quantidade de companhias.

A coleta de dados foi feita em fontes secundárias públicas de forma direta pelo próprio pesquisador, utilizando informações disponibilizadas pelo Sistema de Divulgação Externa ITR/DFP/IAN [DIVEXT] da Comissão de Valores Mobiliários [CVM]. Essa forma de obtenção dos dados evita que haja o viés do respondente e o baixo número de respostas quando se trabalha com envio de questionários, e tem sido amplamente utilizada nas pesquisas nacionais e internacionais, como pode ser visto nos trabalhos de Klapper e Love (2002), Leal e Carvalhal-da-Silva (2004), Black et al. (2005), Nobili (2006), Silva e Leal (2007), e, Silveira, Leal, Carvalhal-da-Silva e Barros (2007).

\section{Qualidade das Práticas de Governança Corporativa}

Como proxy para determinar a qualidade das práticas de governança corporativa das empresas não listadas em bolsa, nesta pesquisa será utilizado um Índice de Governança Corporativa das Empresas Brasileiras de Capital Aberto Não Listadas em Bolsa [IGCNL], baseado no questionário aplicado por Silva (2005) em empresas familiares, que adaptou o questionário desenvolvido por Leal e Carvalhalda-Silva (2004) desenvolvido para as empresas listadas em bolsa. O índice será calculado a partir de um conjunto de 14 perguntas binárias e objetivas, cujas respostas foram obtidas exclusivamente por meio de dados secundários. Cada resposta positiva adiciona um ponto ao índice, com as empresas apresentando nível de governança de 0 a 14. O índice construído contempla três dimensões para a avaliação das práticas de governança: Transparência; Composição e Funcionamento do Conselho; e Controle e Conduta. Na dimensão Transparência foram verificados os seguintes quesitos: elaboração dos relatórios financeiros dentro do prazo legal, contabilização segundo normas internacionais, contratação de auditoria global, divulgação da remuneração do diretor geral e membros do conselho, e presença de parecer de auditoria independente sem ressalvas. Para a dimensão Composição e Funcionamento do Conselho foram observados os seguintes itens: distinção entre as funções de presidente e diretor do conselho, composição do conselho por membros externos e independentes, número de membros do conselho e duração do mandato de seus membros. Já na dimensão Controle e Conduta, os itens observados foram: existência de investigação ou condenação pela CVM, existência de grupo controlador com menos de $50 \%$ das ações com direito a voto, porcentagem das ações sem direito a votos menor que $20 \%$ do capital total e existência de acordos de acionistas.

\section{ANÁLISE DOS RESULTADOS}

\section{Perfil das Empresas não Listadas em Bolsa}

Neste item será apresentada a caracterização das empresas brasileiras de capital aberto não listadas em bolsa, considerando a distribuição dessas empresas segundo o setor de atividade e a região de localização.

A distribuição segundo os setores de atividade foi feita conforme a classificação apresentada no Sistema de Divulgação Externa [DIVEXT] da Comissão de Valores Mobiliários [CVM]. Os resultados obtidos são mostrados na Tabela 1 a seguir. 
Tabela 1

Distribuição das Empresas segundo o Setor de Atividade

\begin{tabular}{|c|c|c|c|c|c|c|c|c|c|c|}
\hline \multirow{2}{*}{ Setor de Atividade } & \multicolumn{2}{|c|}{2003} & \multicolumn{2}{|c|}{2004} & \multicolumn{2}{|c|}{2005} & \multicolumn{2}{|c|}{2006} & \multicolumn{2}{|c|}{2007} \\
\hline & Qtd & $\%$ & Qtd & $\%$ & Qtd & $\%$ & Qtd & $\%$ & Qtd & $\%$ \\
\hline $\begin{array}{l}\text { Empresas administradoras de } \\
\text { participações }\end{array}$ & 24 & 20,0 & 9 & 17,0 & 20 & 21,3 & 7 & 8,9 & 8 & 12,5 \\
\hline Arrendamento mercantil & 21 & 17,5 & 9 & 17,0 & 12 & 12,8 & 8 & 10,1 & 10 & 15,6 \\
\hline Energia Elétrica & 8 & 6,7 & 3 & 5,7 & 3 & 3,2 & 5 & 6,3 & 2 & 3,1 \\
\hline Securitização de recebíveis & 8 & 6,7 & 2 & 3,8 & 8 & 8,5 & 12 & 15,2 & 9 & 14,1 \\
\hline $\begin{array}{l}\text { Const. Civil, mat. de construção e } \\
\text { decoração }\end{array}$ & 7 & 5,8 & 3 & 5,7 & 5 & 5,3 & 3 & 3,8 & 2 & 3,1 \\
\hline Saneamento e serviços de água e gás & 7 & 5,8 & 3 & 5,7 & 5 & 5,3 & 6 & 7,6 & 5 & 7,8 \\
\hline Serviços de transporte e logística & 6 & 5,0 & 5 & 9,4 & 7 & 7,4 & 7 & 8,9 & 7 & 10,9 \\
\hline Têxtil e vestuário & 5 & 4,2 & 1 & 1,9 & 5 & 5,3 & 3 & 3,8 & 3 & 4,7 \\
\hline Hospedagem e turismo & 4 & 3,3 & 1 & 1,9 & 3 & 3,2 & 1 & 1,3 & 2 & 3,1 \\
\hline $\begin{array}{l}\text { Máquinas, equipamentos, veículos e } \\
\text { peças }\end{array}$ & 4 & 3,3 & 5 & 9,4 & 4 & 4,3 & 4 & 5,1 & 4 & 6,3 \\
\hline Metalurgia e siderurgia & 3 & 2,5 & 2 & 3,8 & 1 & 1,1 & 3 & 3,8 & 1 & 1,6 \\
\hline Papel e celulose & 3 & 2,5 & 1 & 1,9 & 3 & 3,2 & 1 & 1,3 & 0 & 0,0 \\
\hline Telecomunicações & 3 & 2,5 & 1 & 1,9 & 2 & 2,1 & 2 & 2,5 & 1 & 1,6 \\
\hline $\begin{array}{l}\text { Química, petroquímica, combustíveis e } \\
\text { borracha }\end{array}$ & 3 & 2,5 & 2 & 3,8 & 3 & 3,2 & 2 & 2,5 & 1 & 1,6 \\
\hline Agricultura (açúcar, álcool e cana) & 2 & 1,7 & 2 & 3,8 & 1 & 1,1 & 1 & 1,3 & 1 & 1,6 \\
\hline Alimentos & 2 & 1,7 & 0 & 0,0 & 1 & 1,1 & 1 & 1,3 & 1 & 1,6 \\
\hline Bancos & 2 & 1,7 & 1 & 1,9 & 3 & 3,2 & 4 & 5,1 & 0 & 0,0 \\
\hline Outros & 8 & 6,7 & 3 & 5,7 & 8 & 8,5 & 9 & 11,4 & 7 & 10,9 \\
\hline Total & 120 & 100 & 53 & 100 & 94 & 100 & 79 & 100 & 64 & 100 \\
\hline
\end{tabular}

Nota. Os dados são relativos aos anos de 2003 a 2007. Esta tabela apresenta a quantidade e o percentual de empresas por setor de atividade. A amostra de cada ano é apresentada no final da tabela.

Fonte: os autores.

Como pode ser observado, alguns setores possuem uma quantidade relevante de empresas abertas não listadas na Bovespa, a exemplo de administração de participações; arrendamento mercantil; securitização de recebíveis; construção civil, material de construção e decoração; saneamento e serviços da água e gás; serviços de transporte e logística; têxtil e vestuário; e, máquinas, equipamentos, veículos e peças. A quantidade de empresas e o percentual dos setores de atividade identificados são apresentados na Tabela 1. Embora com menor número de empresas, outros setores também compõem a amostra, a exemplo de: comunicação e informática, crédito imobiliário, embalagens, extração mineral, factoring, gráficas e editoras, petróleo e gás, reflorestamento, e serviços médicos.

Em seguida foi feita a distribuição das empresas investigadas segundo sua região de localização, e os resultados são mostrados na Figura 2. 


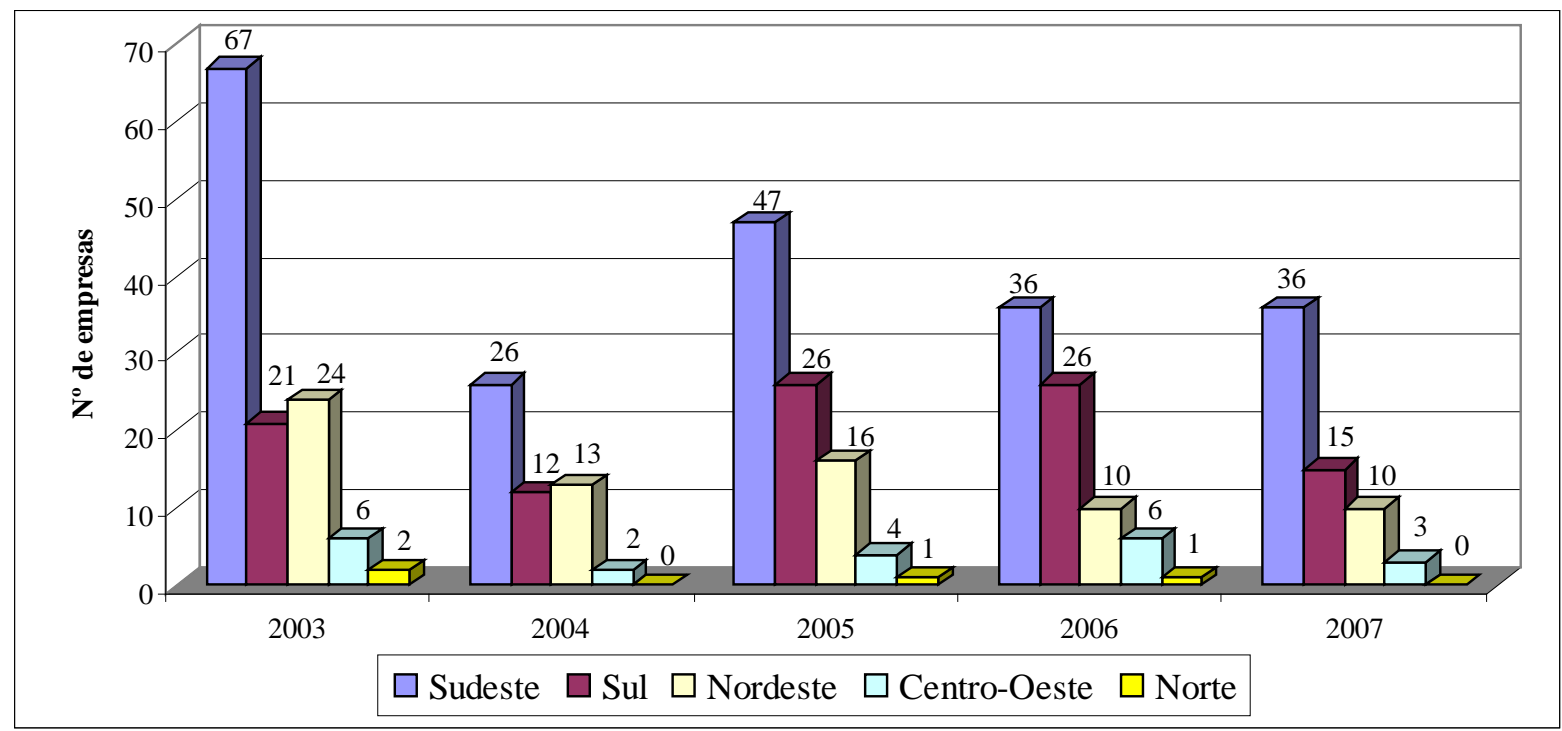

Figura 2. Distribuição das Empresas por Região

Fonte: os autores.

Conforme destaca a Figura 2, há maior número de empresas abertas não listadas em bolsa nas regiões Sudeste, Sul e Nordeste. As regiões Centro-Oeste e Norte são as que possuem menor quantidade dessas empresas.

Essa distribuição das empresas no Brasil foi identificada por outros estudos, que também destacaram uma concentração nas regiões Sudeste e Sul.

\section{Indicador da Qualidade das Práticas de Governança Corporativa}

Para identificar a qualidade das práticas de governança corporativa das empresas abertas não listadas na Bovespa, foi utilizado o questionário aplicado por Silva (2005) em empresas familiares, que adaptou o questionário desenvolvido por Leal e Carvalhal-da-Silva (2004).

Considerando as 14 questões que compõem o Índice de Governança Corporativa das Empresas Brasileiras de Capital Aberto Não Listadas em Bolsa [IGCNL], a tabela 2 apresenta os percentuais de respostas positivas para cada questão nos anos investigados (2003 a 2007). O índice construído contempla três dimensões: Transparência (5 questões); Composição e Funcionamento do Conselho (4 questões); e Controle e Conduta (5 questões).

Na Tabela 2 é destacado ainda que, para cada questão nos anos analisados, os percentuais de respostas positivas são muito próximos para todos os anos. Em relação à dimensão Transparência, verifica-se que as empresas abertas não listadas em bolsa têm elaborado seus relatórios financeiros, obedecendo aos prazos legais (Q1). Tem-se observado que há melhora neste quesito, pois o percentual das empresas que publicam dentro do prazo estipulado tem aumentado, chegando a 93,8\% em 2007. Por outro lado, em todos os anos não foi observada a publicação desses relatórios segundo os padrões internacionais de contabilidade (Q2), conforme aqueles recomendados pelo IASB ou USGAAP. Isto demonstra que essas empresas não sinalizam preparação para ingressarem nos níveis diferenciados de governança corporativa da Bovespa, que possuem três segmentos de mercado, aos quais as empresas podem aderir espontaneamente, atendendo progressivamente a regras mais severas de governança corporativa, e o que é recomendado pela CVM. 
Tabela 2

Respostas do Questionário para Composição do Índice de Governança Corporativa das Empresas Brasileiras de Capital Aberto Não Listadas em Bolsa [IGCNL]

\begin{tabular}{|c|c|c|c|c|c|c|}
\hline & Dimensões de Governança & 2003 & 2004 & 2005 & 2006 & 2007 \\
\hline \multicolumn{7}{|c|}{ Transparência } \\
\hline Q1 & $\begin{array}{l}\text { A companhia prepara seus relatórios } \\
\text { financeiros exigidos por lei dentro do prazo } \\
\text { previsto? }\end{array}$ & $80,0 \%$ & $75,5 \%$ & $83,0 \%$ & $89,9 \%$ & $93,8 \%$ \\
\hline Q2 & $\begin{array}{l}\text { A companhia utiliza métodos internacionais } \\
\text { de contabilidade (IASB ou USGAAP)? }\end{array}$ & $0,0 \%$ & $0,0 \%$ & $0,0 \%$ & $0,0 \%$ & $0,0 \%$ \\
\hline Q3 & $\begin{array}{l}\text { A companhia usa uma das principais } \\
\text { empresas de auditoria globais? }\end{array}$ & $55,0 \%$ & $49,1 \%$ & $50,0 \%$ & $48,1 \%$ & $43,8 \%$ \\
\hline Q4 & $\begin{array}{l}\text { A companhia apresenta no seu website ou } \\
\text { nas informações anuais informações (IAN) } \\
\text { sobre a remuneração do diretor geral e dos } \\
\text { membros do conselho? }\end{array}$ & $78,3 \%$ & $58,5 \%$ & $70,2 \%$ & $69,6 \%$ & $56,3 \%$ \\
\hline Q5 & $\begin{array}{l}\text { A empresa teve parecer de auditoria } \\
\text { independente sem ressalvas? }\end{array}$ & $69,2 \%$ & $66,0 \%$ & $70,2 \%$ & $74,7 \%$ & $78,1 \%$ \\
\hline \multicolumn{7}{|c|}{ Composição e Funcionamento do Conselho } \\
\hline Q6 & $\begin{array}{l}\text { O presidente do conselho e o diretor geral da } \\
\text { empresa são pessoas diferentes? }\end{array}$ & $58,3 \%$ & $58,5 \%$ & $60,6 \%$ & $72,2 \%$ & $69,4 \%$ \\
\hline Q7 & 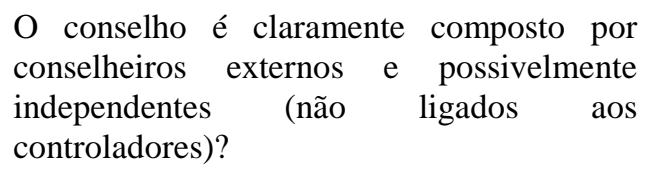 & $22,5 \%$ & $26,4 \%$ & $28,7 \%$ & $29,1 \%$ & $20,3 \%$ \\
\hline Q8 & $\begin{array}{l}\text { O conselho possui entre } 5 \text { e } 9 \text { membros, } \\
\text { conforme recomenda o código do IBGC? }\end{array}$ & $41,7 \%$ & $37,7 \%$ & $34,0 \%$ & $40,5 \%$ & $29,7 \%$ \\
\hline Q9 & $\begin{array}{l}\text { Os membros do conselho têm mandato de } \\
\text { um ano, conforme recomenda o código do } \\
\text { IBGC? }\end{array}$ & $25,0 \%$ & $26,4 \%$ & $23,4 \%$ & $24,1 \%$ & $18,8 \%$ \\
\hline \multicolumn{7}{|c|}{ Controle e Conduta } \\
\hline Q10 & $\begin{array}{l}\text { A empresa não está sob investigação em } \\
\text { curso ou tem qualquer tipo de condenação } \\
\text { pela CVM no último ano? }\end{array}$ & $98,3 \%$ & $86,8 \%$ & $98,9 \%$ & $98,7 \%$ & $84,4 \%$ \\
\hline Q11 & $\begin{array}{l}\text { O grupo controlador, considerando os } \\
\text { acordos de acionistas, possui menos de } 50 \% \\
\text { das ações com direito a voto? }\end{array}$ & $22,5 \%$ & $0,0 \%$ & $10,6 \%$ & $13,9 \%$ & $25,6 \%$ \\
\hline Q12 & $\begin{array}{l}\text { A porcentagem das ações sem direito a } \\
\text { votos é menor que } 20 \% \text { do total do capital? }\end{array}$ & $65,8 \%$ & $62,3 \%$ & $58,5 \%$ & $70,9 \%$ & $64,1 \%$ \\
\hline Q13 & O controle da companhia é direto? & $32,5 \%$ & $32,1 \%$ & $41,5 \%$ & $41,8 \%$ & $29,7 \%$ \\
\hline Q14 & Não existem acordos de acionistas? & $72,5 \%$ & $81,1 \%$ & $87,2 \%$ & $84,8 \%$ & $85,9 \%$ \\
\hline
\end{tabular}

Nota. Percentuais de respostas positivas às perguntas do questionário para as empresas brasileiras de capital aberto não listadas em bolsa. A amostra é composta por 120 empresas em 2003, 53 empresas em 2004, 94 empresas em 2005, 79 empresas em 2006 e 64 empresas em 2007. Fonte: os autores. 
Em seguida, foi investigado se as empresas foram auditadas por uma das grandes auditorias globais (Delloite, Ernest \& Young, KPMG e PricewaterhouseCoopers). Nesta questão (Q3) foi observado que cerca da metade das companhias de cada ano foram auditadas por empresa de padrão mundial; foi um pouco reduzido em 2007, quando apenas 43,8\% dessas companhias tiveram pontuação positiva neste quesito. Quanto à remuneração do diretor geral e dos membros do conselho (Q4), no sentido inverso à boa transparência das informações, há uma queda no percentual de empresas que publicam esta informação, atingindo o menor índice de divulgação (56,3\%) em 2007. Já em relação à presença de parecer de auditoria sem ressalvas (Q5), pode-se dizer que há melhora na qualidade das preparações das demonstrações financeiras auditadas, uma vez que há aumento de quase 9\% no percentual de empresas que apresentaram parecer sem ressalva, tendo em 2007 atingido o patamar de 78,1\%, sendo bom indicador das práticas de governança.

Para a dimensão Composição e Funcionamento do Conselho, um dos itens analisados foi a separação entre as funções de presidente do conselho e diretor da empresa (Q6). Houve evolução neste quesito, partindo de 58,3\% das empresas investigadas em 2003; em 2006 atingiu o maior percentual $(72,2 \%)$. Talvez isso se deva a alguma característica das empresas que não têm ações negociadas em bolsa de valores, mas é um ponto de conflito de interesses entre os papéis que desempenham o gestor e presidente do conselho, que cuida dos interesses de todos acionistas. Por outro lado, poucas empresas apresentam conselheiros independentes (Q7), tendo o maior número sido observado em 2006, com 29,1\% da amostra. Portanto não há boa evolução, em termos de governança, neste quesito. Outra questão investigada foi se a quantidade de membros do conselho está entre 5 e 9 (Q8), conforme recomenda o IBGC. Constatou-se que 41,7\% dessas empresas atendiam a esta recomendação em 2003, reduzindo-se em 2005 para 34\%, e, em 2007, para 29,7\%. As empresas parecem cumprir apenas o mínimo exigido por lei. Quanto ao prazo de mandato dos membros do conselho (Q9), observou-se que houve uma redução no número de empresas com mandato de um ano (renováveis) para seus conselheiros; chegou apenas a 18,8\% das empresas pontuado positivamente, em 2007, nessa questão. Pode-se dizer que a Composição e Funcionamento do Conselho não apresentou sinais de melhoria ao longo dos anos analisados, uma vez que o atendimento das exigências em relação à quantidade de membros, independência e prazo de mandato diminuíram, principalmente no último ano.

Já em relação à dimensão Controle e Conduta, verificou-se a ausência de investigação ou de qualquer tipo de condenação pela CVM (Q10) em mais de 84\% das empresas nos anos pesquisados. Há variação ao longo dos anos na quantidade de empresas sem ter tido problemas desta natureza, mas mantém-se em níveis elevados. A presença de um grupo controlador com menos da metade das ações com direito a voto (Q11) das empresas abertas não listadas na Bovespa mostrou-se baixo em todos os anos, confirmando a alta concentração de ações de controle, observada em outros trabalhos nas empresas de capital aberto. Em 2004, foi verificado que o grupo controlador é composto somente por acionistas com mais de 50\% do capital votante, o que indica a existência de uma estrutura de propriedade bastante concentrada. Na questão Q12 constatou-se ainda que a porcentagem de ações sem direito a voto menor que $20 \%$ do capital votante é sempre superior a $58,5 \%$, em todos os anos pesquisados para essas empresas, atingindo 70,9\% em 2006. A maioria das empresas possui quantidade relativamente baixa de ações preferenciais, o que pode ser também uma característica deste grupo de empresas não listadas, pois é um tipo mais difícil de ser negociada fora do mercado de ações organizado. Quanto ao tipo de controle, foi observado o controle direto (Q13) em pelo menos 30\% das empresas, em todos os anos. Na última questão (Q14), em que foi pesquisada a inexistência de acordos entre acionistas, observou-se que a grande maioria das empresas não possuíam acordos, chegando a ter, em 2007, aproximadamente $86 \%$ de empresas sem ele. Em síntese, os resultados da estrutura de Controle e Conduta das empresas abertas não listadas não tiveram grandes alterações, ao longo dos anos pesquisados; entretanto o último quesito pesquisado foi o que teve maior evolução positiva no sentido de boas práticas de governança, porquanto, segundo a teoria referenciada, acordos podem servir de instrumento para expropriar acionistas minoritários.

Com relação à pontuação obtida pelas empresas abertas não listadas para cada uma das dimensões do índice (subíndices), que são Transparência, Composição e Funcionamento do Conselho, e Controle e Conduta, os resultados são apresentados a seguir. 


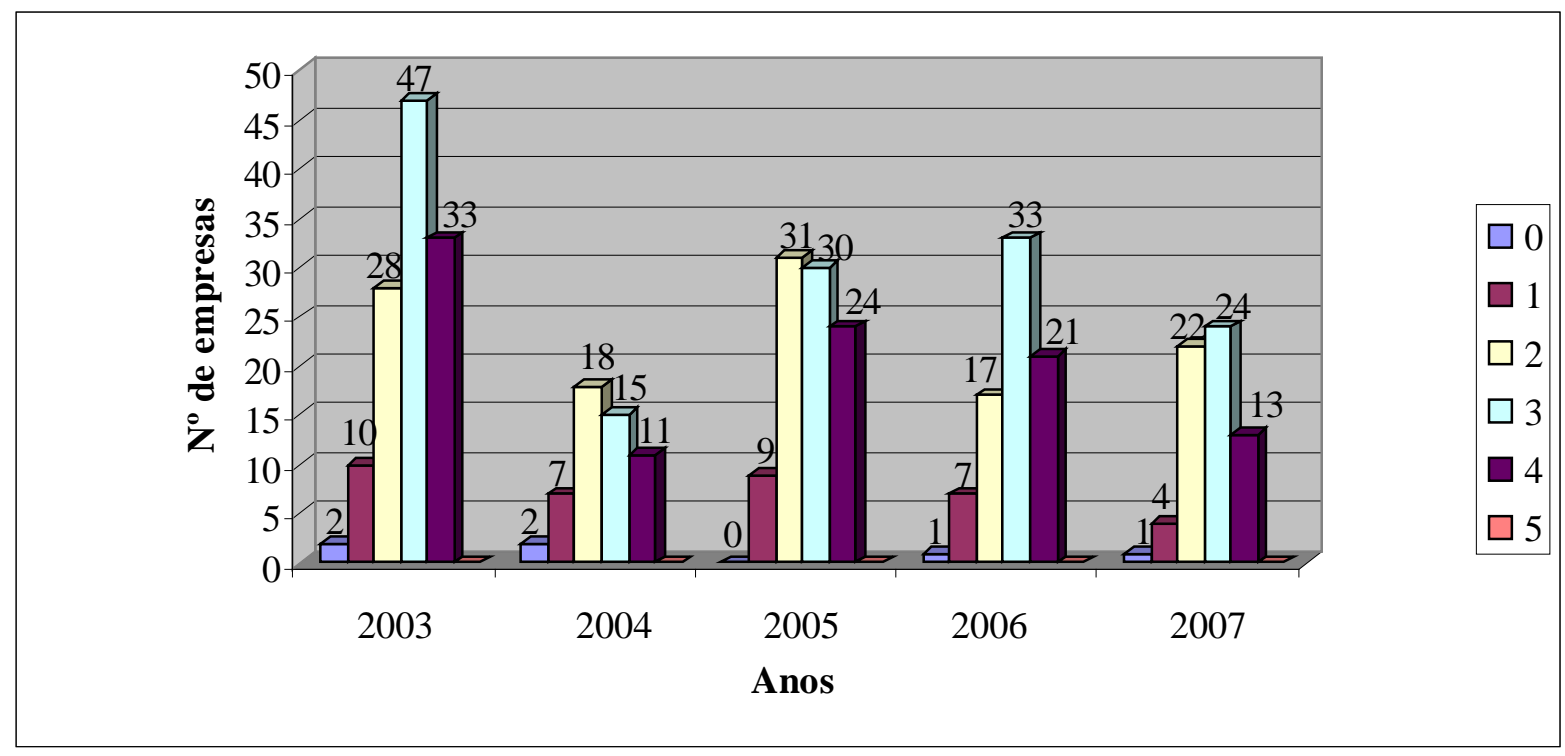

Figura 3. Pontuação do Subíndice Transparência das Empresas Abertas não Listadas em Bolsa Fonte: os autores.

No que se refere ao subíndice Transparência, as empresas poderiam obter uma pontuação que varia de 0 a 5 em cada ano, cujos resultados são apresentados na Figura 3. Quanto aos resultados para este subíndice, no período de 2003 a 2007, maior número de empresas obteve pontuação que varia entre 2 e 4 pontos; destaque-se também que, neste item específico, nenhuma delas atingiu a pontuação máxima de 5 pontos. Em 2007, obtiveram 3 pontos neste subíndice, 24 empresas abertas não listadas na Bovespa, o que representa 38\% da amostra deste ano. Esta dimensão é muito importante e tem apresentado melhores pontuações entre as empresas de capital aberto com ações na Bovespa. Acreditase que a falta de pressão do mercado influencie as empresas pesquisadas a não terem maiores preocupações em ser transparentes e, também, ao perfil dos acionistas deste tipo de empresas.

Quanto à dimensão Composição e Funcionamento do Conselho, as empresas abertas não listadas na Bovespa poderiam obter uma pontuação que varia de 0 a 4 . Os resultados obtidos são apresentados na Figura 4 a seguir.

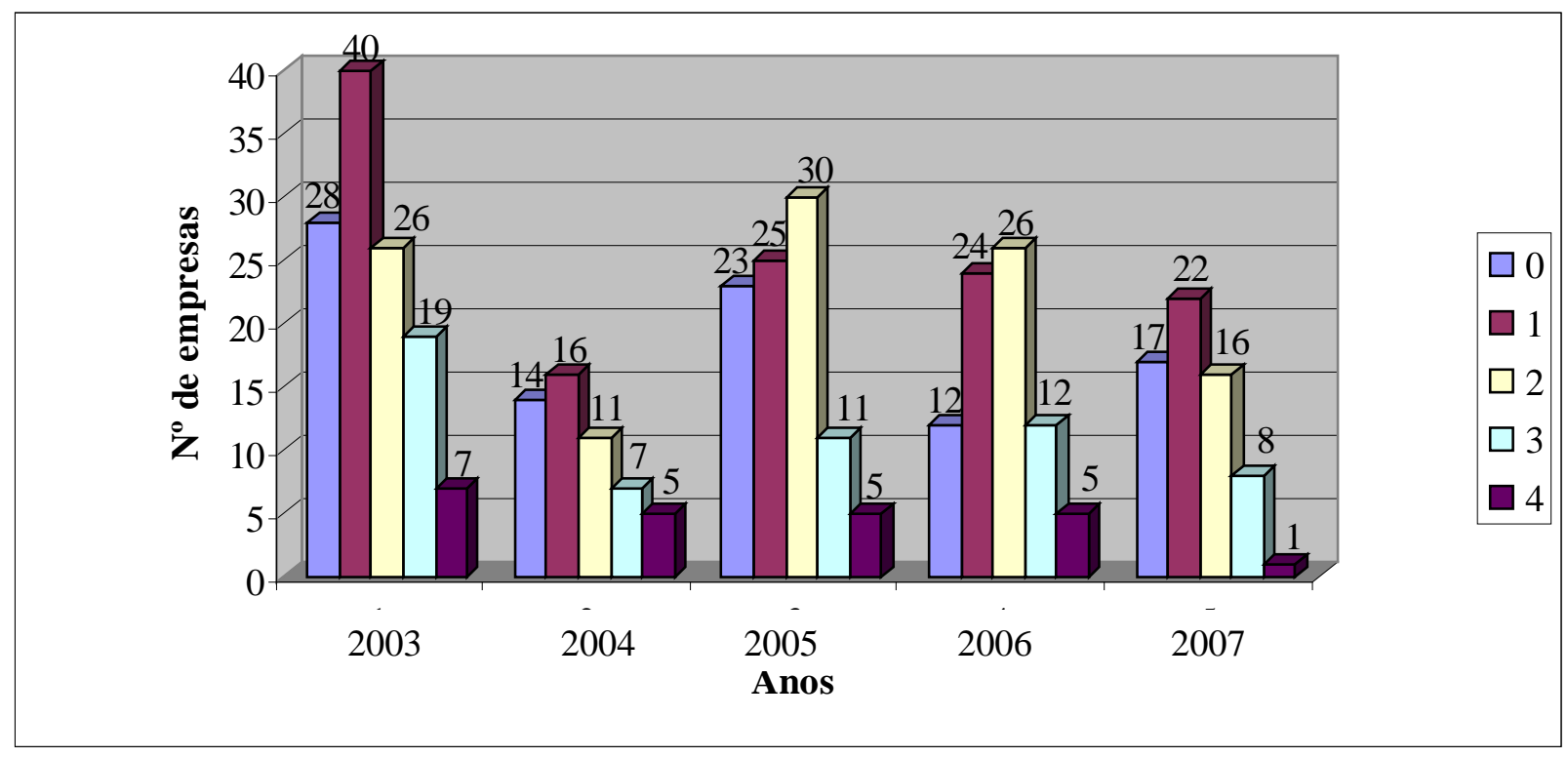

Figura 4. Pontuação da Dimensão Composição e Funcionamento do Conselho das Empresas Abertas não Listadas em Bolsa

Fonte: os autores. 
A Figura 4 destaca que a maior parcela das empresas abertas não listadas em bolsa apresentaram pontuação entre 0 e 2 pontos para a dimensão Composição e Funcionamento do Conselho. Em 2007, 22 empresas (34\%) atingiram somente um ponto na composição deste subíndice, demonstrando a necessidade de melhor adequação do conselho de administração às práticas de governança corporativa.

Na dimensão Controle e Conduta, cuja pontuação poderia variar entre 0 e 5, (ver Figura 5) observase que a maior parte das empresas obteve 3 pontos em todos os anos e que nenhuma empresa obteve pontuação igual a zero. Destaca-se que, em 2007, a pontuação máxima foi atingida por duas empresas (3\%).

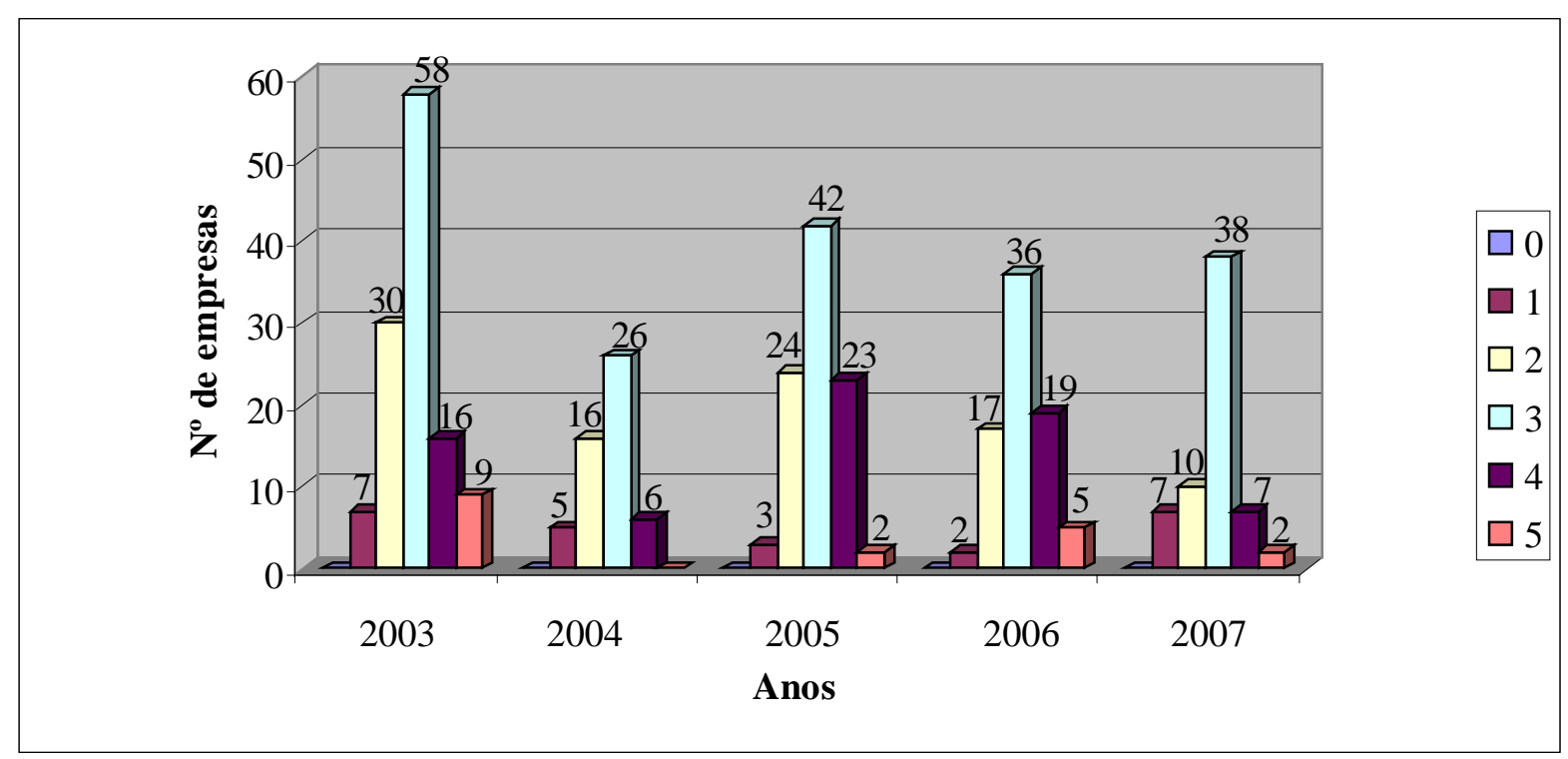

Figura 5. Pontuação na Dimensão Controle e Conduta das Empresas Abertas não Listadas Fonte: os autores.

A análise conjunta das três dimensões pode ser feita com o Índice de Governança Corporativa das Empresas Brasileiras de Capital Aberto Não Listadas em Bolsa (Figura 6).

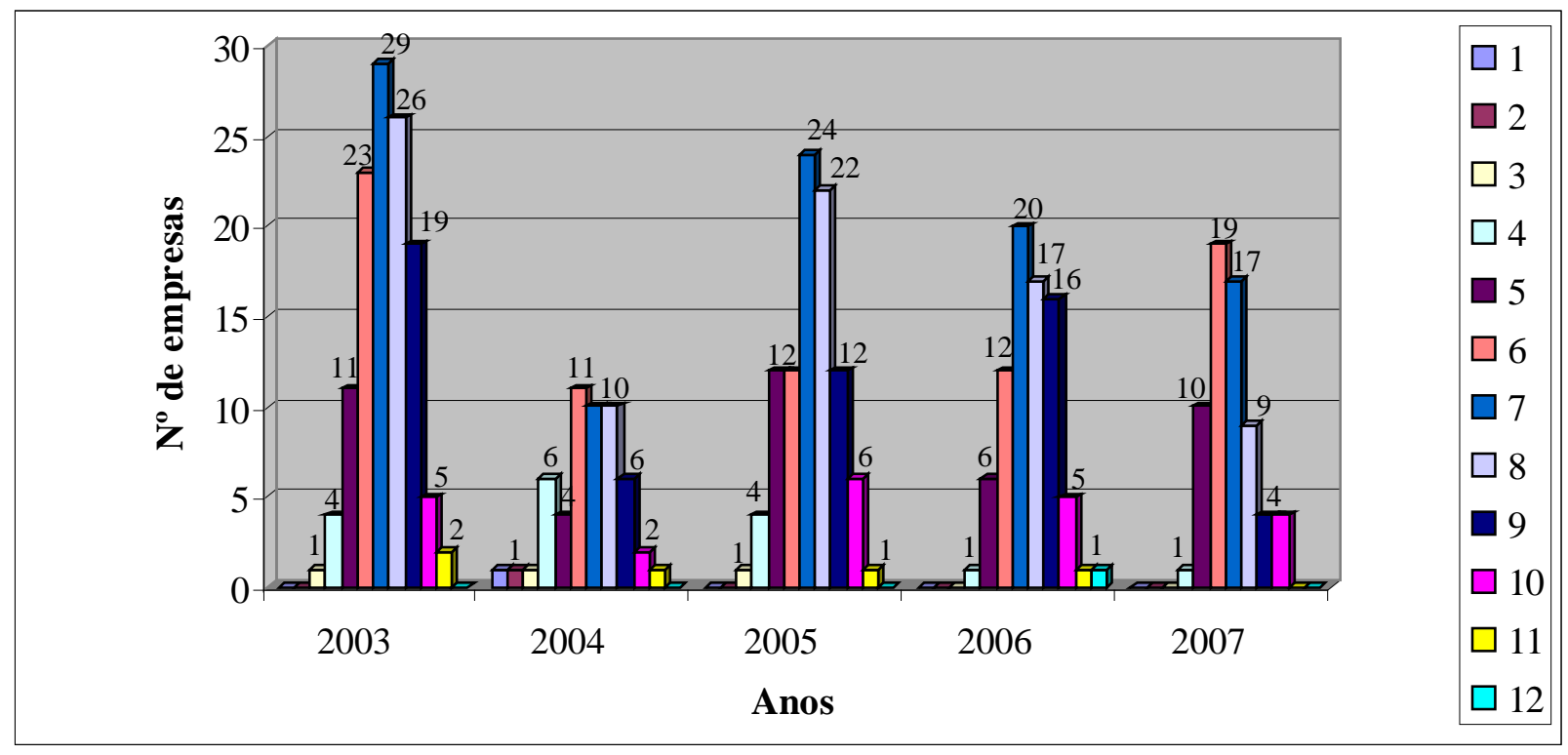

Figura 6. Pontuação do Índice IGCNL das Empresas Abertas não Listadas em Bolsa Fonte: os autores. 
Ainda em relação ao Índice IGCNL e suas dimensões, são apresentados a seguir as estatísticas descritivas (média e mediana) de cada uma delas.

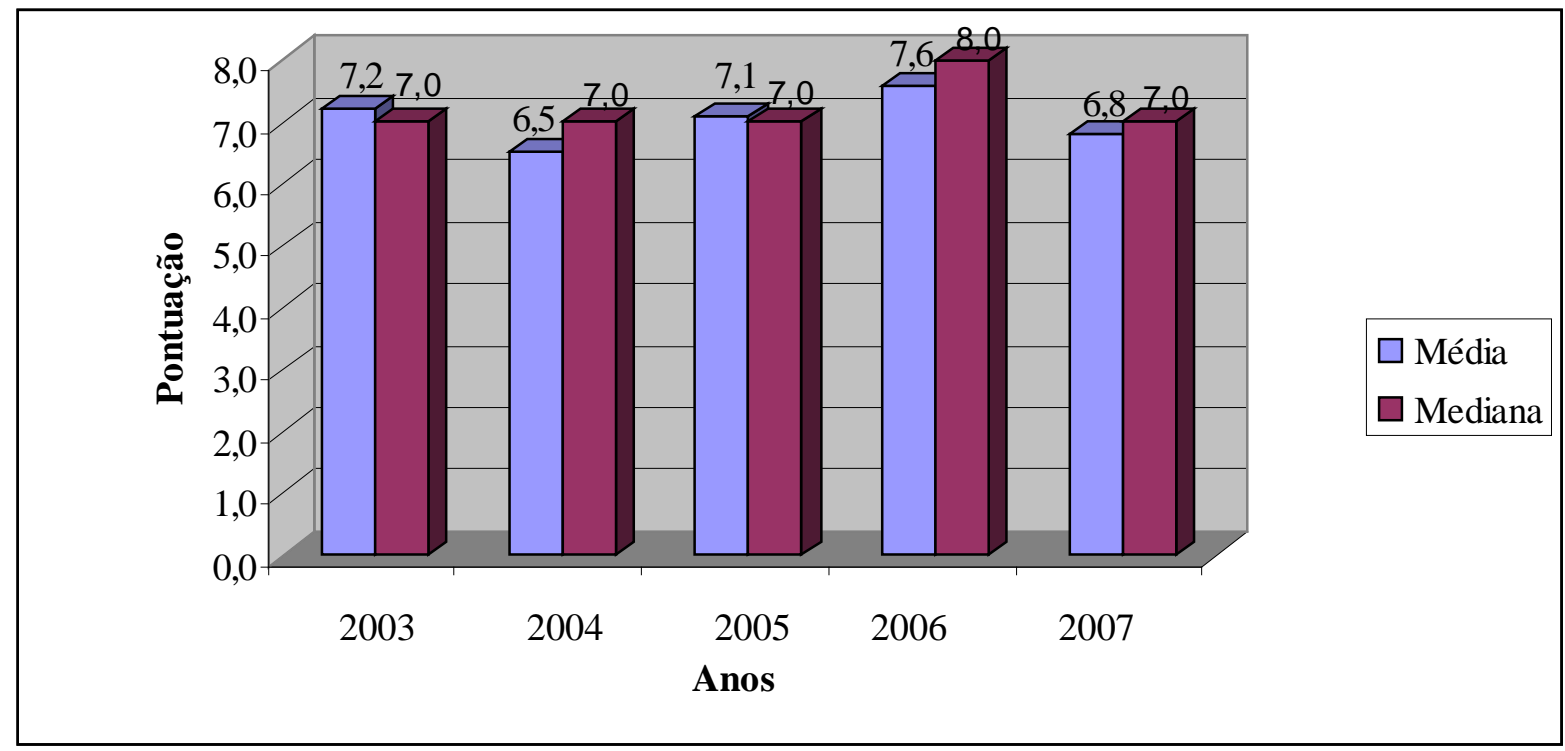

Figura 7. Estatísticas Descritivas do Índice IGCNL das Empresas Abertas não Listadas em Bolsa Fonte: os autores.

Os resultados da Figura 7 mostram que, em todos os anos analisados, as empresas de capital aberto que não atuam na Bovespa obtiveram pontuação média igual ou superior a 6,5, e que metade dessas empresas apresentou bom nível de governança corporativa, com mediana igual ou superior a 7 pontos, embora a pontuação máxima atingida tenha sido 12 pontos em 2006, conforme se mostra na Figura 6.

Em seguida, foram investigados os setores e as regiões que apresentaram melhores pontuações no índice IGCNL. Os resultados são apresentados na Tabela 3.

Tabela 3

\section{Melhor Pontuação do Índice IGCNL segundo o Setor de Atividade e a Região}

\begin{tabular}{ccll}
\hline Ano & Pontuação & \multicolumn{1}{c}{ Setor de Atividade } & Região \\
\hline 2003 & 11 & $\begin{array}{l}\text { Const. Civil, mat. de construção e decoração } \\
\text { Securitização de recebíveis }\end{array}$ & Sudeste \\
\hline 2004 & 11 & Empresas administradoras de participações & Sudeste \\
2005 & 11 & Empresas administradoras de participações & Sudeste \\
2006 & 12 & Papel e celulose & Sudeste \\
\hline 2007 & 10 & Empresas administradoras de participações & Sudeste \\
& & Máquinas, equipamentos, veículos e peças & Nordeste \\
\hline
\end{tabular}

Nota. Fonte: os autores.

Nesta tabela observa-se que sobressai o setor das empresas administradoras de participações como o que apresentou melhor pontuação no índice IGCNL em 2004, 2005 e 2007. Quanto à região, destaca- 
se a Sudeste que concentra as empresas com melhores práticas de governança, ressaltando que esta região é a que também apresenta maior representatividade da amostra conforme mostrado na Figura 2.

\section{CONSIDERAÇÕES FINAIS}

O presente estudo teve como objetivo analisar a evolução da qualidade das práticas de governança corporativa das empresas brasileiras de capital aberto não listadas em bolsa de valores, no período de 2003 a 2007.

Em relação à dimensão Transparência, verificou-se que há melhora na elaboração de relatórios financeiros, obedecendo aos prazos legais, apesar de que a publicação desses relatórios não é feita nos padrões das normas internacionais de contabilidade recomendadas pelo IASB ou USGAAP. Em contrapartida, destacou-se que cerca de metade das companhias foram auditadas por alguma das auditorias globais. Por outro lado, no sentido inverso à boa transparência, verificou-se que há queda no percentual de empresas que publicaram a informação a respeito da remuneração do diretor geral e dos membros do conselho. Já em relação ao parecer de auditoria, pode-se dizer que há melhora na qualidade das preparações das demonstrações financeiras auditadas, uma vez que há aumento das empresas que apresentaram parecer sem ressalva, sendo bom indicador das práticas de governança. Ainda em relação à Transparência, maior número de empresas obteve pontuação que varia entre 2 e 4 pontos, destacando-se que nenhuma delas atingiu a pontuação máxima de 5 pontos.

Quanto à dimensão Composição e Funcionamento do Conselho, observou-se que é crescente a preocupação das empresas em fazer separação entre as funções de presidente do conselho de administração e diretor geral. Por outro lado, ainda são poucas as empresas que possuem conselheiros externos e possivelmente independentes, ou seja, não ligados aos controladores. Em relação à quantidade de membros do conselho, houve redução das empresas com a quantidade de membros entre 5 e 9, conforme recomenda o IBGC. Quanto ao prazo de mandato dos membros do conselho, observou-se que houve redução no número de empresas com mandato de um ano (renováveis) para seus conselheiros. Nesta dimensão do índice IGCNL, a maior parcela das empresas abertas não listadas em bolsa apresentaram pontuação entre 0 e 2 pontos.

Já em relação à dimensão Controle e Conduta, verificou-se que a maior parte das empresas não está sob investigação ou de qualquer tipo de condenação pela CVM. Por outro lado, a presença de um grupo controlador com menos da metade das ações com direito a voto mostrou-se baixo em todos os anos, confirmando a alta concentração de ações de controle. Quanto ao tipo de controle, foi observado o controle direto em pelo menos $30 \%$ das empresas em todos os anos. No que se refere à existência de acordos entre acionistas, observou-se que a grande maioria das empresas não possuía acordos. Este quesito pesquisado foi o que teve maior evolução positiva no sentido de boas práticas de governança, pois os acordos podem servir de instrumento para expropriar acionistas minoritários. Quanto à pontuação, na dimensão do índice, observou-se que a maior parte das empresas obtiveram 3 pontos em todos os anos e que nenhuma empresa ficou com pontuação igual a zero.

No que diz respeito à qualidade das práticas de governança corporativa, observou-se que metade das empresas investigadas apresentou bom nível de governança corporativa, com mediana superior a 7 pontos em todos os anos. Quando observadas as melhores pontuações dos índices por setor de atividade e região, destacou-se o setor das empresas administradoras de participações como o que apresentou melhor pontuação no índice IGCNL em 2004, 2005 e 2007; a região Sudeste concentra as empresas com melhores práticas de governança e é também aquela que possui maior representatividade da amostra.

Assim, em linhas gerais, a análise do período em estudo permite afirmar que as dimensões Transparência e Controle e Conduta apresentaram bons resultados, ao passo que a estrutura de Composição e Funcionamento do Conselho precisa ser melhorada. 
A principal limitação da pesquisa refere-se ao tamanho da amostra, dada a variação da quantidade de empresas de um ano para outro. Para futuros estudos sugere-se que seja feita a mesma pesquisa com empresas listadas com a finalidade de realizar comparações entre os dois grupos de empresas, listadas e não listadas, e verificar se existem diferenças importantes entre elas.

Artigo recebido em 10.06.2009. Aprovado em 26.01.2010.

\section{AGRADECIMENTOS}

Os autores agradecem a CAPES, CNPq, FACEPE e Programa THESIS/UFS pelo auxílio financeiro recebido.

\section{REFERÊNCIAS BIBLIOGRÁFICAS}

Ariff, A. M., Ibrahim, M. K., \& Othman, R. (2007). Determinants of firm level governance: Malaysian evidence. Corporate Governance, 7(5), 562-573.

Beiner, S., Drobetz, W., Schmid, M., \& Zimmerman, H. (2003). An integrated framework of corporate governance and firm valuation - evidence from Switzerland [Working Paper $\mathrm{N}^{\circ}$ 09-03]. ECGI. $\begin{array}{lllll}\text { Recuperado em } & 15 & \text { junho, }\end{array}$ http://www.wwz.unibas.ch/cofi/publications/papers/2003/09-03.pdf

Berle, A. A., \& Means, G. C. (1932). The modern corporation and private property. New York: MacMillan.

Black, B. (2001). The corporate governance behavior and market value of Russian firms. Emerging Markets Review, 2(2), 89-108.

Black, B., Jang, H., \& Kim, W. (2005). Does corporate governance affect firms' market value? Time series evidence from Korea. [Working Paper $\mathrm{N}^{0}$ 103]. European Corporate Governance Institute. Recuperado em 15 junho, 2008, de http://www.law.uchicago.edu/Lawecon/workshoppapers/black-jang-kim-stanford.pdf

Bolsa de Valores de São Paulo. (2008). IGC e o novo mercado. Recuperado em 22 março, 2008, de http://www.bovespa.com.br/Principal.asp

Drobetz, W., Gugler, K., \& Hirschvogl, S. (2004). The determinants of german corporate governance rating. Recuperado em 15 junho, 2008, de http://www.wwz.unibas.ch/forum/volltexte/749.pdf

Gompers, P. A., Ishii, J. L., \& Metrick, A. (2003). Corporate governance and equity prices. Quarterly Journal of Economics, 118(1), 107-155.

Instituto Brasileiro de Governança Corporativa. (2004). Código das melhores práticas de governança corporativa. Recuperado em 22 março, 2008, de http://www.ibgc.org.br/download/arquivos/Codigo_IBGC_3_versao.pdf

Jensen, M. C., \& Meckling, W. H. (1976). Theory of the firm: managerial behavior, agency costs, and ownership structure. Journal of Financial Economics, 3(4), 305-360.

Klapper, L., \& Love, I. (2002) Corporate Governance, investor protection, and performance in emerging markets [Working Paper No 2818]. World Bank Policy Research, Washington, District of Columbia, Estados Unidos. 
Leal, R. P. C., \& Carvalhal-da-Silva, A. L. (2004). Corporate governance index, firm valuation and performance in Brazil [Working Paper $\mathrm{N}^{\circ}$ 358]. COPPEAD/Universidade Federal do Rio de Janeiro, Rio de Janeiro, RJ, Brasil.

Lei $n^{\circ}$ 6.404/76, de 15 de dezembro de 1976. (1976). Dispõe sobre as Sociedades por Ações. Recuperado em 22 março, 2008, de http://www.planalto.gov.br/ccivil_03/Leis/L6404consol.htm

Lei $n^{\circ}$ 10.303/01, de 31 de outubro de 2001. (2001). Altera e acrescenta dispositivos na Lei no 6.404, de 15 de dezembro de 1976, que dispõe sobre as Sociedades por Ações, e na Lei no 6.385, de 7 de dezembro de 1976, que dispõe sobre o mercado de valores mobiliários e cria a Comissão de Valores Mobiliários. Recuperado em 22 março, 2008, de http://www.planalto.gov.br/ccivil_03/LEIS/LEIS_2001/L10303.htm

Nobili, C. B. (2006). Governança corporativa e retornos esperados no mercado acionário brasileiro: uma extensão do modelo de três fatores de fama \& french. Dissertação de mestrado, COPPEAD/Universidade Federal do Rio de Janeiro, Rio de Janeiro, RJ, Brasil.

Oliveira, R. V. (2006, outubro). A Lei Sabanes-Oxley como nova motivação para mapeamento de processos nas organizações. Anais do Encontro Nacional de Engenharia de Produção, Fortaleza, CE, Brasil, 26.

Organisation for Economic Co-Operation and Development. (2005). Corporate governance of nonlisted companies in emerging markets. Paris: Author.

Organisation for Economic Co-Operation and Development. (2008). Corporate govenance. Recuperado em 22 março, 2008, de http://www.oecd.org/home/0,2987,en_2649_201185_1_1_1_1_1,00.html

Shleifer, A., \& Vishny, R. W. (1997). A survey of corporate governance. The Journal of Finance, 52(2), 737-783.

Silva, J. F. (2005). Governança corporativa das empresas familiares brasileiras de capital aberto listadas e não-listadas em bolsa. Tese de doutorado, COPPEAD/Universidade Federal do Rio de Janeiro, Rio de Janeiro, RJ, Brasil.

Silva, J. F., \& Leal, R. P. C. (2007, julho). Práticas de governança em empresas familiares não-listadas de capital aberto. Anais do Encontro Brasileiro de Finanças, Rio de Janeiro, RJ, Brasil, 7.

Silveira, A. M. (2004). Governança corporativa e estrutura de propriedade: determinantes e relação com o desempenho das empresas no Brasil. Tese de doutorado, FEA/Universidade de São Paulo, São Paulo, SP, Brasil.

Silveira, A. M., Leal, R. P. C., Carvalhal-da-Silva, A. L., \& Barros, L. A. B. C. (2007). Evolution and determinants of firm-level corporate governance quality in Brazil. Recuperado em 15 dezembro, 2007, de http://papers.ssrn.com/sol3/papers.cfm?abstract_id=995764 